\title{
PSYCHOLOGICAL AND HISTORICAL OVERVIEW OF TRADE UNIONS
}

\begin{abstract}
Humans have always been gregarious creatures, initially organizing themselves in tribes. This model allowed individuals to survive by means of mutual help. The same relationship can be observed in the trade union movement. A worker caring for their interests alone has less ability to achieve a given purpose than an organization which acts collectively. The history of trade unions started in Great Britain, which is viewed as the cradle of communities of working people. the union movement developed in several stages running differently in different legal realities. The article below presents the trade unions from a psychological and historical perspective including the attempt to answer the question about the reasons for the decline in unionization.
\end{abstract}

Słowa kluczowe: związki zawodowe, kolektywizm, człowiek w społeczeństwie, pracownicza potrzeba przynależności

Key words: trade unions, collectivism, man in society, employee need of belonging

"Anyone who either cannot lead the common life or is so self-sufficient as not to need to, and therefore does not partake of society, is either a beast or a god".

Aristotle

\section{Introduction}

Humans are social beings who have always lived in communities. This statement is the starting point for most analyses of the researched subject. To determine the psychological and historical facets of trade union membership, several issues need to be explored. Firstly, it has to be established why people feel the need to belong to a group. Secondly, it must be pointed out why a person feels the need to belong to a particular social group - a trade union. This will allow us to determine the psychological relationships that are formed in the work environment as a result of workers ' membership in a union. In doing so, it is important to present the historical basis of trade union activity. Trade unions did not always exist. It is therefore important to point out what socio-economic 
phenomena have influenced the rise of the trade union movement. Since man is by nature a creature living in communities, why did people not always feel the need to create collective labour movement? What influenced the need for this?

\section{Man as a social being from the perspective of the scope of labour unionization}

Social participation has to be seen as a strong and universal motivation of human actions. ${ }^{1}$ Man has always been looking for opportunities to belong to specific groups. It seems trivial to say that man is not a lonely island. The definition of man as a social being consists, among other things, of the recognition that man lives in a community. Man therefore has a network of various social connections with other individuals, thus actively contributing to the formation of society. ${ }^{2}$ Social bonds (networks) enable individuals to survive and develop, allowing them to achieve their goals more easily. ${ }^{3}$ Among people functioning in a community there are different types of contact that can come into existence. First of all, there is spatial contact which arises because certain persons function in the same living space. There is also psychological contact connected with the belief that another person can be useful, and social contact related to bonds between people who represent convergent values. ${ }^{4}$ All these contacts are important in determining the reasons for establishing a particular social relationship.

The factors that condition the motivation for accessing particular groups embrace:

1) sense of security - group membership reduces loneliness resulting in increased self-confidence;

2) status - group membership is considered to be important for the recognition and prestige of its members;

3) high self-esteem - groups improve the self-esteem of their members both in the eyes of the members of the group as well as those outside the group;

4) sense of belonging - groups meet social needs, which is why people enjoy belonging to groups;

5) strength - group activities are more likely to succeed than individual undertakings;

6) achieving goals - achieving some goals is impossible alone - it requires the combination of skills of different people. ${ }^{5}$

${ }^{1}$ B. Wojciszke, Psychologia społeczna (Social psychology), Warszawa 2013, p. 47.

2 E. Stroińska, Człowiek jako istota społeczna (Man as a social being); http://estroinska.swspiz.pl/ userfiles/file/SOCJALIZACJA.doc, 2008, p. 1 (accessed: 14.03.2018).

${ }^{3}$ W. Iżyk, Więzi społeczne i ich element, in: Socjologia pracy z elementami psychologii pracy, W. Iżyk (ed.) (Social bond and its elements, in: Sociology of work with elements of work psychology), Wrocław 1990, p. 6.

${ }^{4}$ Ibidem, p. 6-8.

${ }^{5}$ S.P. Robbins, Organizational Behaviour (Zachowania w organizacji), New Jersey 1998, p. 165. 
The above enumeration shows that individuals join groups, above all else, to achieve a goal that cannot be achieved individually. ${ }^{6}$ Such a goal can be, for example, the improvement of employment conditions. The analysis leads us to the conclusion that man, as an entity programmed to gather in groups, creates social relationships in the workplace because acting through such relationships is a better method of achieving the intended goal. This makes workers create trade unions for the protection of their rights.

Groups which are created in society can be formal or informal. ${ }^{7}$ In order to determine whether labour unions are formal or informal social groups, specific circumstances have to be taken into account. Employee movements can arise as informal relationships between colleagues and then transform into formal groups (labour unions) regulated by law. On the other hand, formalized relationships existing based on law regulations may develop, to become informal, intimate and friendly, but still retain their original character. Therefore, labour union groups can be defined as both formal and informal, depending on the reference point and the stage of its development.

The sociology of the organization allows us to classify trade unions into groups defined as stable. Such groups require the loyalty of their members and provide them with considerable support. ${ }^{8}$ Trade unions are characterized by a common front against the employer and the state. This common front defines the goals of the trade union. Each group must define its group goals. These goals cannot be a value for particular individuals alone and must reflect the needs and aspirations of all members of the group. ${ }^{9}$

Acting in a group brings a number of advantages that affect individuals' emotional side. Group activities satisfy the need for belonging, help identify oneself as an entity, give support, set limits between what is desirable and what is undesirable (what is good and bad). Group actions are more effective through i.e.:

- mutual motivation and support;

- using the competence of various people with different talents;

- mutual complementation of defects;

- creating new values by combining knowledge. ${ }^{10}$

Due to the fact that most emotions are experienced in relation to other people, any group experience affects one's emotional life. This provides an insight into the emotions related to the ability to cope with different situations. A social bond can, of course, produce negative emotions, too. However, they usually affect the individual in a positive way, giving them emotional support, consolation and practical help. ${ }^{11}$ As regards trade unions ' protection of workers' interests, social support is important at all

${ }^{6}$ J. Jasińska, Grupy społeczne w organizacji, in: Socjologia organizacji: problemy podstawowe, J. Łucewicz

(ed.) (Social groups in the organization, in: Sociology in organization: Basic problems), Wrocław 1995, p. 25.

7 Ibidem, p. 55.

${ }^{8}$ Ibidem, p. 57.

${ }^{9}$ Ibidem, p. 50.

${ }^{10}$ B. Wojciszke, Psychologia społeczna, p. 464.

${ }^{11}$ Ibidem, p. 48. 
the above-mentioned levels. An employee who is aware of the support from the union feels more confident knowing that they are not alone with their problem.

Trade unions should therefore be regarded as a special form of social relations. On the one hand, their formalized activity is important due to the fact that they are called upon to protect the rights and interests of employees. On the other hand, they give employees a sense of belonging to a community that is characterized by common goals. Such a feeling is important both from the perspective of the perception of humans as a social being and the perspective strictly related to the performance of the employment relationship, as will be discussed later.

\section{Trade union membership from the viewpoint of general human needs and job satisfaction}

Relationships connected with work affect human life in different contexts. Work influences not only one's economic well-being, but one's sense of dignity and self-respect. From this point of view a trade union, as the advocate and agent of the worker in obtaining both income and dignity, has an obvious potential for affecting an individual's satisfaction with life. ${ }^{12}$ Direct benefits to individuals from union membership and participation include e.g. social connectedness and a sense of community. ${ }^{13}$ Trade unions fulfil the role of a gathering group for achieving employees' goals. Trade union membership has an unequivocal impact on the growth of the sense of social belonging. For example, union members are more likely to vote in presidential and congressional elections, regardless of such individual characteristics as income, education, and occupation. ${ }^{14}$ It would be useful to examine the interaction of the identified phenomena. Does the sense of community derived from union membership extend to other social attitudes, or do people with a developed sense of belonging join both trade unions and take part in presidential elections? Trade unions have always made significant contributions to workers' health and welfare. All the goals of traditional union organization and activism are focused on contributing to the welfare of individuals and families. As statistical data indicate, in 2011 the median take-home pay in the US for union workers was $\$ 917$ a week compared with $\$ 717$ for non-union workers. ${ }^{15}$ Union membership clearly affects the overall situation of the individual ensuring a better realization of workers' rights.

12 A.K. Dutt, B. Radcliff, Introduction, in: Happiness, Economics and Politics: Toward a MultiDisciplinary Approach, A.K. Dutt, B. Radcliff (eds.), (Wstęp, w: Szczęście, ekonomia i polityka: w kierunku podejścia wielodyscyplinarnego, Cheltenham, UK, Northampton, MA, USA 2009, p. 15.

${ }_{13}$ B. Lott, Social Class Myopia: The Case of Psychology and Labor Unions (Krótkowzroczność klasy społecznej: przypadek psychologii i związków zawodowych), The University of Rhode Island, Psychology Faculty Publications, 2014, p. 17.

${ }^{14}$ Ibidem, p. 18.

15 Ibidem, p. 15. 
A trade union as a social group must determine the scope of its aspirations. It is obviously adapted to the current situation. A trade union, in pursuit of the set goals, enables one to meet their needs connected with the working environment. ${ }^{16}$ It would probably be impossible to meet these needs while acting alone. Trade union membership, as a tool for achieving individual goals through collective actions, is at the same time a manifestation of the necessity of belonging to specific groups.

Trade union membership has also other measurable benefits. People who can count on social support are resistant to stress, which makes their lives longer and qualitatively better. ${ }^{17}$ For example, the awareness that, in the event of dismissal, an employee will be represented by an institution defending their rights, relatively reduces stress caused by the dismissal.

Employees belonging to trade unions feel more professional satisfaction. ${ }^{18}$ This is because they have a sense of influence over the decision-making process, which in turn results in better identification with the existing rules. One of the 15 . factors mentioned as a condition of job satisfaction is the satisfaction with participation in management. If a worker has an impact on the process of work, he feels more satisfied with the job. The employee should feel involved in the work management process. ${ }^{19}$ An employee's influence on decisions makes him feel that he makes every effort to ensure himself and his family a dignified life. ${ }^{20}$ This, as already indicated, results in increased job satisfaction

\section{Workplace relationships in the context of trade union membership}

Relationships in the workplace will be presented from two perspectives - the perspective of a psychological contract and the three-entity relation: employee-employer-trade union. The consideration of the psychological contract approach should begin with stating briefly what a psychological contract is. A psychological contract is a commitment between parties that represents mutual beliefs and perceptions of informal obligations between an employer and an employee. ${ }^{21} \mathrm{~A}$ psychological contract presents the subjective expectations that cannot be confirmed by the other party. By executing a psychological contract, an individual recognizes that their contribution to the relationship justifies

${ }^{16}$ S. Korczyński, Funkcjonowanie człowieka $w$ organizacji (Man functioning in the organization), Opole 2011, p. 23.

${ }_{17}$ B. Wojciszke, Psychologia społeczna, p. 48.

18 S. Leka, A. Jain, Health Impact of Psychosocial Hazards at Work: An Overview (Wpływ zagrożeń psychospołecznych w pracy na zdrowie: przeglad), Geneva 2010, p. 50.

19 S. Korczyński, Funkcjonowanie człowieka w organizacji, p. 76.

20 B. Lott, Social Class Myopia..., p. 17.

${ }^{21}$ D.M. Rousseau, Psychological and implied contracts in organizations (Kontrakt psychologiczny i dorozumiany w organizacji), Employee Responsibilities and Rights Journal 1989, 2 (2), p. 123. 
the reciprocation of the contribution by the other party. ${ }^{22} \mathrm{~A}$ psychological contract is maintained at the employee-employer relationship level. It cannot be implemented by collectives (e.g. trade unions). ${ }^{23}$ What is the connection between a psychological contract and a union? The relationship between a psychological contract breach and union commitment is stronger when individuals perceive that their union is highly instrumental in protecting their rights and benefits. ${ }^{24}$ Therefore, the stronger the trade union, the stronger the obligations resulting from the psychological contract. A psychological contract is executed to a high degree by an employee if they feel that they can expect the employer to meet their obligations. If the employer does not fulfil their obligations voluntarily, it can be done under the pressure of a trade union. From this perspective, it is crucial for an employee to determine the extent to which a union is perceived as able to put pressure on the employer to fulfil the psychological contract. What is more, when a psychological contract existing between an employee and an employer is breached, the degree to which individuals are more attracted to the union is likely to be strongly influenced be the extent to which these individuals believe that union can help them improve their working conditions. ${ }^{25}$ From the above it follows that the relationship between the psychological contract and trade union membership occurs on different levels interacting with each other.

Trade unions can be categorized as social policy actors, pursuing the aims and tasks that are part of them. ${ }^{26}$ One of the main goals of social policies are those related to the conditions of work. In this sense, the role of trade unions is not to be overestimated. An employer, while managing an enterprise, should act in a way that fosters interpersonal relationships, including trade unions. This will not only help fulfil social policy objectives, but also increase employee identification with the workplace. One of the social goals of work is employees' participation in deciding on the work process. ${ }^{27}$ As long as the employer and the trade union will carry out their goals in a non-conflictual manner, the postulate proclaimed by Aristotle will be fulfilled. He assumed that only friendly

${ }^{22} \mathrm{~K}$. Adamska, Kontrakt psychologiczny w organizacji - Kwestionariusz Kontraktu Psychologicznego (Psychological contract in the organization - Questionnaire of the Psychological Contract), Psychologia Społeczna 2011, 6 (3), p. 268.

${ }^{23}$ A. Rogozińska-Pawełczyk, Zarządzanie zasobami ludzkimi oparte na kontrakcie psychologicznym (Human resources management based on a psychological contract), Warszawa 2016, p. 109.

${ }^{24}$ W.H. Thurnley, M.C. Bolino, S.W. Lester, J.M. Bloodgood, The effects of psychological contract breach on union commitment (Wplyw naruszenia kontraktu psychologicznego na zaangażowanie w przynależność do związków zawodowych), Journal of Occupational and Organizational Psychology 2004, 77, p. 421.

${ }^{25}$ Ibidem, p. 423.

${ }^{26}$ R. Śmietański, Związki zawodowe jako podmiot realizujący cele i zadania polityki społecznej. Wybrane zagadnienia: działalność socjalna i edukacyjna (Trade unions as an entity pursuing the goals and objectives of social policy. Selected issues: social and educational activities), Wrocławskie Studia Politologiczne 2013, 15, p. 38.

27 A. Kubów, Warunki pracy i organizacja miejsca pracy, in: Socjologia pracy z elementami psychologii pracy, W. Iżyk (ed.) (Working conditions and workplace organization, in: Sociology of work with elements of work psychology), Wrocław 1990, p. 56. 
relations between people fulfil the principles of justice. ${ }^{28}$ For proper employee relations, particularly important are those practices that focus on creating a climate of engagement with decisions made in the organization. ${ }^{29}$ The fulfilment of this postulate cannot take place through conflict.

There are also close links between workers and trade unions. When employees believe that their organization has treated them well, they are likely to feel positively toward their organization and engage in behaviours that will support it. ${ }^{30}$ The above results from the fact that there is a separate psychological contract exists also in the employee-union relation. This contract is executed by an employee with full engagement when they see the full involvement of the other party (trade union).

Relations between all participants (employee-employer-trade union) form a mutually interconnected network of relationships. These relationships most often result from legal regulations, which, for example, provide the basis for the exercise of trade union rights. The above analysis, however, indicates that the activity associated with collective employee representation also influences the psychological dependence of employee behaviour.

\section{Historical background of trade union movement}

Looking for the precursor of the union movement, it is worth paying attention to the guild of craftsmen activity. Guilds had control over the entry to the trade, they ensured standards and quality of work, and even controlled the prices of goods. Therefore, the scope of their activities was much larger than the scope of trade unions. When discussing the formation of trade unions in their present form, it is crucial to point out the different stages of this process. The first period was a period of an absolute and sanctioned ban on the establishment of trade unions. In England it derived from the Combination Acts adopted in 1799-1800 and operating until $1825 .{ }^{31}$ Those Acts made any form of strike illegal and punishable. ${ }^{32}$ In France prohibition of the formation of trade unions was introduced in 1791 by the Loi le Chapelier Act (in force until 1864). In Germany this prohibition originated from the times of the guild system and was repealed in $1869 .{ }^{33}$

${ }^{28}$ I. Andrzejczuk, Arystotelesowska koncepcja społeczności jako ludzi powiązanych przyjaźniq (Aristotles' conception of the community as people linked by friendship); http://katedra.uksw.edu.pl/publikacje/publikacje_start.htm, 2012, p. 10 (accessed: 04.01.2018).

${ }^{29}$ K. Adamska, Kontrakt psychologiczny w organizacji..., p. 270.

${ }^{30}$ W.H. Thurnley, M.C. Bolino, S.W. Lester, J.M. Bloodgood, The effects of psychological contract..., p. 422 .

${ }^{31}$ M. Święcicki, Prawo pracy (Labour law), Warszawa 1968, p. 73.

${ }^{32}$ Claiming rights: Role of trade unions in the UK (Prawa do dochodzenia roszczeń: rola zwiazków zawodowych w Wielkiej Brytanii); http://www.striking-women.org/module/rights-and-responsibilities/ claiming-rights-role-trade-unions-uk (accessed: 04.01.2018).

${ }^{33}$ M. Święcicki, Prawo pracy. 
The second period was related to allowing the formation of trade unions by repealing the prohibitions mentioned above. At the time, however, the activity of trade unions had no legal basis. They gained it in the third period - the period of recognition. ${ }^{34}$ Issued by British legislation in the 1871, Trade Union Act recognised unions as legal entities entitled to protection under the law. However, it was only in 1875 that it was legal for trade unions to take effective strike action by picketing (Conspiracy and Protection of Property Act 1875). ${ }^{35}$ In France the equivalent of the aforementioned statutes was the act of 1884 on syndicates. It allowed the establishment of trade unions without the need for prior approval of the administration, while granting the both positive and negative freedom of the coalition (freedom of association and freedom of expression). In Germany this period cannot be separated because the legal acts that underpin the activity of trade unions were not issued. The last stage, which continues to this day, is the stage of trade unions ' activity. Its beginning can be traced back to the end of the First World War when trade unions became a representative of the interests of the working class. ${ }^{36}$

The first trade unions began to emerge in the lands belonging to Poland at the end of the $19^{\text {th }}$ century. This process began in Silesia, primarily in Gliwice, Bytom, Katowice and Tarnowskie Góry (in the Kingdom of Prussia). In 1889 the Mutual Assistance Association was established in this area. It was the first mass organization of a trade union in lands belonging to Poland. In 1902 the Polish Professional Union was formed. It focused on Polish workers from Rhineland and Westphalia. ${ }^{37}$ The above is just a historical chronology of events. It is important, however, to paint the socio-economic background.

The point at which labour movement first emerged has to be connected with industrialization, resulting in the ability to mass-produce in factories and the division of those who controlled work and those who massively produced goods. Also, in this period the so-called class consciousness developed. The struggle of workers to improve their situation resulting from their appalling material and social situation was strengthened. Political parties, established massively in the 80 s and $90 \mathrm{~s}$ of $19^{\text {th }}$ century, assisted workers in this struggle, by proclaiming postulates of improving the position of the whole working class. Bad working conditions have resulted in the solidarity of the working class. Common goals, aimed at achieving better living conditions, united workers. They had three possibilities: they could strive to become bourgeois; they could allow themselves to be ground down; or they could rebel. ${ }^{38}$

Since the $19^{\text {th }}$ century the trade unions have represented a large social group on whom socioeconomic development was dependent. Obtaining the subjectivity of the trade unions has made it reasonable to consult legal changes in the social and economic

${ }^{34}$ Ibidem.

${ }^{35}$ Claiming rights...

${ }^{36}$ M. Święcicki, Prawo pracy, p. 74.

${ }^{37}$ Historia powstania związków zawodowych (The history of rising of trade unions); http://www.solidarnosc-icn.pl/index.php?option=com_content\&view=article\&id=48\&Itemid=63 (accessed: 04.01.2018).

${ }^{38}$ E. Hobsbawm, The Age of Revolution: 1789-1848 (Wiek rewolucji: 1789-1848), London 1962, p. 245. 
system with them. ${ }^{39}$ Trade unions gained significance as a subject of social policy after the Second World War in Western Europe and North America, when social action was intensified, giving trade unions a real opportunity to influence the shaping of social policy. ${ }^{40}$ The circumstances of creating trade unions and the process strengthening of their position confirm the adequacy of the conclusions drawn in the section on the psychological aspects of forming trade unions. The bad life situation of workers and the need to improve it led them to take collective action. As a group they were more powerful in achieving common goals. Are those trends and motivations still valid?

A change in the employees' attitude to relationships in the work environment results in a decrease in unionization. Nowadays the employee is more focused on achieving individual goals and relying on oneself rather than joining the organized trade union structures. ${ }^{41}$ Traditional employment relationships based on strict subordination and conviction of collective strength gives way to more direct, partner relationships. This is primarily due to the promotion of individual patterns of behaviour and flexible forms of employment tailored to individual needs. ${ }^{42}$ 'Post-Fordism' (seen as the organizational and technological changes that have taken place in industry; the influence of current international competition; changes in the labour market; the emergence of new forms of personnel management; the replacement of public property by private property; an increasing number of small companies; and the perceived spread of a new, individualistic ideology) transforms trade unions into outdated institutions. Traditional working class employed by large factories is gradually disappearing, whereas the number of workers employed on fixed-term or part-time contracts is increasing. Employees are no longer permanently attached to one workplace. ${ }^{43}$ Globalization is another factor that may influence the strength of trade unions. Because of privatization, deregulation, job insecurity, and lower wages, which are the results of globalization trade unions became weaker. Moreover, fluctuations in business cycles, inflation, and unemployment rates also play a role in the strength of trade unions in several countries around the world. ${ }^{44}$ All these factors are seen as tending to reduce trade union membership and its influence.

39 R. Śmietański, Związki zawodowe i ich wpływ na rozwój społeczny i gospodarczy (Trade unions and their influence on social and economic development), Studia Ekonomiczne. Zeszyty Naukowe Uniwersytetu Ekonomicznego w Katowicach 2014, 167, p. 232.

40 R. Śmietański, Związki zawodowe jako podmiot..., p. 39.

${ }^{41}$ A. Rogozińska-Pawełczyk, Od relacyjnego do transakcyjnego kontraktu psychologicznego - zmieniajacy sie paradygmat (From a relational to a transactional psychological contract: changing the paradigm), Zarządzanie Zasobami Ludzkimi 2011, 3-4, p. 67.

42 Z. Ratajczak, Psychologia pracy i organizacji (Work psychology and organization), Warszawa 2007, p. 103.

${ }^{43} \mathrm{~J}$. Gradowski, Problems facing the trade union movement analysed (Analiza problemów ruchu zwiazkowego); https://www.eurofound.europa.eu/observatories/eurwork/articles/problems-facing-thetrade-union-movement-analysed, 2003, p. 1 (accessed: 04.01.2018).

${ }^{44} \mathrm{Ch}$. Napathorn, S. Chanprateep, What types of factors can influence the strength of labor unions in companies and state enterprises in Thailand? (Jakie czynniki moga wplywać na wzmocnienie pozycji 


\section{Summary}

Since the rise and intensified activity of trade unions, the value systems that underpin the idea of social solidarity have changed. The socio-economic conditions associated with working have also changed. As all social ties are weakening, so is the bond associated with the sense of need for collective participation in managing the work process. Unionization thrives when employees feel disrespected, unsafe, underpaid and unappreciated. Then they see unions as a viable option. ${ }^{45}$ In developed countries the labour market has become the market of an employee. On the other hand, in developing countries, where the situation of workers is still very bad, they cannot see any sense in undertaking collective action, as they will not achieve their goal. What is more, all over the world the proportion of younger people who choose to join unions is declining dramatically, suggesting that young generations do not see membership in a collective employee body as necessary or desirable. The tradition of employee representation through trade unions is being replaced by new relationships in the workplace. The replacement is not of a single type - it comprises a number of different trends. In some cases the traditional model is retained, in other increased individualism predominates, and yet in other cases a partnership approach is adopted. In this approach unions take some of the concerns of the organization and work with management. ${ }^{46}$ Time will tell how collective employee actions will be aligned with the current needs of the labour market and social needs of employees.

\section{References}

Adamska K., Kontrakt psychologiczny w organizacji - Kwestionariusz Kontraktu Psychologicznego (Psychological contract in the organization - Questionnaire of the Psychological Contract), Psychologia Społeczna 2011, 6 (3).

Andrzejczuk I., Arystotelesowska koncepcja społeczności jako ludzi powiązanych przyjaźniq (Aristotles' conception of the community as people linked by friendship); http://katedra.uksw. edu.pl/publikacje/publikacje_start.htm, 2012 (accessed: 04.01.2018).

Anyango Ch., Obange N., Abeka E., Ondiek G.O., Odera O., Ayugi M.E., Factors affecting performance of trade unions in Kenya (Czynniki wpływające na działalność związków zawodowych w Kenii), American Journal of Business and Management 2013, 2 (2).

związków zawodowych w strukturach pracodawców prywatnych i państwowych w Tajlandii?), International Journal of Business and Management 2011, 6 (2), p. 113.

${ }^{45}$ Ch. Anyango, N. Obange, E. Abeka, G.O. Ondiek, O. Odera, M.E. Ayugi, Factors affecting performance of trade unions in Kenya (Czynniki wplywające na działalność związków zawodowych w Kenii), American Journal of Business and Management 2013, 2 (2), p. 181.

46 Ibidem, p. 182 and literature indicated there. 
Claiming rights: Role of trade unions in the UK (Prawa do dochodzenia roszczeń: rola zwiazków zawodowych w Wielkiej Brytanii); http://www.striking-women.org/module/rights-and-responsibilities/claiming-rights-role-trade-unions-uk (accessed: 04.01.2018).

Dutt A.K., Radcliff B., Introduction, in: Happiness, Economics and Politics: Toward a Multi-Disciplinary Approach, A.K. Dutt, B. Radcliff(eds.), (Wstęp, w: Szczęście, ekonomia i polityka: w kierunku podejścia wielodyscyplinarnego), Cheltenham, UK, Northampton, MA, USA 2009.

Gradowski J., Problems facing the trade union movement analysed (Analiza problemów ruchu związkowego); https://www.eurofound.europa.eu/observatories/eurwork/articles/problems-facing-the-trade-union-movement-analysed, 2003 (accessed: 04.01.2018).

Historia powstania związków zawodowych (The history of rising of trade unions); http://www. solidarnoscicn.pl/index.php?option=com_content\&view $=$ article\&id=48\&Itemid $=63$ (accesed: 04.01.2018).

Hobsbawm E., The Age of Revolution: 1789-1848 (Wiek rewolucji: 1789-1848), London 1962. Iżyk W., Więzi społeczne i ich element, in: Socjologia pracy z elementami psychologii pracy, W. Iżyk (ed.) (Social bond and its elements, in: Sociology of work with elements of work psychology), Wrocław 1990.

Jasińska J., Grupy społeczne w organizacji, in: Socjologia organizacji: problemy podstawowe, J. Łucewicz (ed.) (Social groups in the organization, in: Sociology in organization: Basic problems), Wrocław 1995.

Korczyński S., Funkcjonowanie człowieka w organizacji (Man functioning in the organization), Opole 2011.

Kubów A., Warunki pracy i organizacja miejsca pracy, in: Socjologia pracy z elementami psychologii pracy, W. Iżyk (ed.) (Working conditions and workplace organization, in: Sociology of work with elements of work psychology), Wrocław 1990.

Leka S., Jain A., Health Impact of Psychosocial Hazards at Work: An Overview (Wpływ zagrożeń psychospołecznych w pracy na zdrowie: przeglad), Geneva 2010.

Lott B., Social Class Myopia: The Case of Psychology and Labor Unions (Krótkowzroczność klasy społecznej: przypadek psychologii i związków zawodowych), The University of Rhode Island, Psychology Faculty Publications, 2014.

Napathorn Ch., Chanprateep S., What types of factors can influence the strength of labor unions in companies and state enterprises in Thailand? (Jakie czynniki moga wplywać na wzmocnienie pozycji związków zawodowych $w$ strukturach pracodawców prywatnych i państwowych $w$ Tajlandii?), International Journal of Business and Management 2011, 6 (2).

Ratajczak Z., Psychologia pracy i organizacji (Work psychology and organization), Warszawa 2007. Robbins S.P., Organizational Behaviour (Zachowania w organziacji), New Jersey1998.

Rogozińska-Pawełczyk A., Od relacyjnego do transakcyjnego kontraktu psychologicznego zmieniajacy sie paradygmat (From a relational to a transactional psychological contract: changing the paradigm), Zarządzanie Zasobami Ludzkimi 2011, 3-4.

Rogozińska-Pawełczyk A., Zarządzanie zasobami ludzkimi oparte na kontrakcie psychologicznym (Human resources management based on a psychological contract), Warszawa 2016.

Rousseau D.M., Psychological and implied contracts in organizations (Kontrakt psychologiczny i dorozumiany w organizacji), Employee Responsibilities and Rights Journal 1989, 2 (2). 
Stroińska E., Człowiek jako istota społeczna (Man as a social being); http://estroinska.swspiz. pl/userfiles/file/SOCJALIZACJA.doc, 2008 (accessed: 14.03.2018).

Śmietański R., Związki zawodowe i ich wpływ na rozwój społeczny i gospodarczy (Trade unions and their influence on social and economic development), Studia Ekonomiczne. Zeszyty Naukowe Uniwersytetu Ekonomicznego w Katowicach 2014, 167.

Śmietański R., Zwiazki zawodowe jako podmiot realizujacy cele i zadania polityki społecznej. Wybrane zagadnienia: działalność socjalna i edukacyjna (Trade unions as an entity pursuing the goals and objectives of social policy. Selected issues: social and educational activities), Wrocławskie Studia Politologiczne 2013, 15.

Święcicki M., Prawo pracy (Labour law), Warszawa 1968.

Thurnley W.H., Bolino M.C., Lester S.W., Bloodgood J.M., The effects of psychological contract breach on union commitment (Wplyw naruszenia kontraktu psychologicznego na zaangażowanie w przynależność do związków zawodowych), Journal of Occupational and Organizational Psychology 2004, 77.

Wojciszke B., Psychologia społeczna (Social psychology), Warszawa 2013. 